\title{
PENGARUH PENGGUNAAN KITOSAN TERHADAP SIFAT BARRIER EDIBLE FILM TAPIOKA TERMODIFIKASI
}

\section{(THE EFFECT OF CHITOSAN USAGE ON THE BARRIER PROPERTIES OF MODIFIED STARCH EDIBLE FILMS)}

\author{
Guntarti Supeni dan Suryo Irawan
}

\author{
Balai Besar Kimia dan Kemasan, Kementerian Perindustrian RI \\ JI. Balai Kimia I Pekayon, Pasar Rebo, Jakarta Timur \\ E-mail : guntartisupeni@yahoo.com
}

Received : 10 Januari 2012; revised : 27 januari 2012; accepted : 11 April 2012

\begin{abstract}
ABSTRAK
Penelitian pengaruh kitosan terhadap sifat barrier edible film tapioka termodifikasi dilakukan. Hal ini dilakukan karena lembaran film yang diperoleh pada penelitian sebelumnya masih memerlukan peningkatan sifat barrier dan kestabilan film pada penyimpanan. Seperti diketahui tapioka bersifat hidrofilik, sehingga perlu campuran bahan yang bersifat hidrofobik. Salah satu bahan yang mempunyai sifat tersebut adalah kitosan, dengan penambahan aditif lain diharapkan dapat memperbaiki sifat film. Tujuan dari penelitian ini adalah untuk mengetahui pengaruh kitosan terhadap sifat barrier edible film tapioka termodifikasi. Penelitian dilakukan dengan metode pencampuran larutan edible film tapioka termodifikasi dengan larutan kitosan. Variabel yang digunakan adalah penambahan konsentrasi kitosan pada larutan edible film tapioka termodifikasi, dengan menitikberatkan parameter uji pada nilai laju $\mathrm{O}_{2} T R$ dan nilai laju WVTR dari edible film yang dihasilkan. Secara umum lembaran film yang dihasilkan masih memiliki laju transmisi uap air (WVTR) yang cukup besar $\left(>200 \mathrm{~g} / \mathrm{m}^{2} / 24\right.$ jam) dan memiliki sifat kedap terhadap oksigen yang cukup baik, ditandai dengan rendahnya nilai laju transmisi oksigen $\left(\mathrm{O}_{2} T R\right)\left(<1 \mathrm{cc} / \mathrm{m}^{2} / 24 \mathrm{jam}\right)$. Penggunaan paling optimal 1:0,75 dihasilkan nilai laju WVTR minimum sebesar $215,48 \mathrm{~g} / \mathrm{m}^{2} / 24$ jam dan nilai laju $\mathrm{O}^{2} \mathrm{TR}$ sebesar $0,376\left(\mathrm{cc} / \mathrm{m}^{2} / 24 \mathrm{jam}\right)$. Pada hasil analisis SEM terlihat bahwa pada penambahan filler kitosan sebesar $75 \%$ mempunyai sifat barrier terhadap uap air yang baik, hal ini disebabkan filler kitosan yang ditambahkan sudah merata mengisi pori-pori atau celah ikatan antar polimer yang terbentuk. Penambahan kitosan tidak dapat meningkatkan grade pada JIS Z 1707-1997, Plastic Film for Food Packaging.
\end{abstract}

Kata kunci : Kitosan, Edible film, Tapioka termodifilkasi

\begin{abstract}
Research on the effects of chitosan on barrier properties of modified tapioca edible films was carried out in order to improve the film sheet obtained in the previous studies, which is still need improvement on their barrier properties and the storage stability of the film. As known tapioca is hydrophilic material, which needs addition of hydropobic materials. Addition of hydropobic material is expected to improve the film properties. The purpose of this research was to determine the effect of chitosan on permeability properties of edible films of modified tapioca. The research was carried out by mixing of a tapioca edible film solution and a chitosan. In this research, the composition of chitosan solution to tapioca edible films are varied with the focus on the $\mathrm{O}_{2}$ TR and WVTR of edible film produced. In general, the WVTR of the film still quite large (> $200 \mathrm{~g} / \mathrm{m}^{2} / 24 \mathrm{jam}$ ), however the impermeability to oxygen is quite well, indicated by low $0.376\left(\mathrm{cc} / \mathrm{m}^{2} / 24 \mathrm{jam}\right)$. The most optimal use is 1:0.75 available values for a minimum WVTR rate and exchange rate of $215.48 \mathrm{~g} / \mathrm{m}^{2} / 24 \mathrm{jam} \mathrm{O}_{2} T R$ of $0.376\left(\mathrm{cc} / \mathrm{m}^{2} / 24 \mathrm{jam}\right)$. SEM analysis shows that the addition of $75 \%$ chitosan have optimal WVTR due to the chitosan evenly fill the pores or gaps between the polymer bonds are formed. Addition chitosan can not improve grade on JIS Z 1707-1997, Plastic Films for Food Packaging.
\end{abstract}

Key words : Chitosan, Edible packaging, Modified starch

\section{PENDAHULUAN}

Pengemasan merupakan proses perlindungan suatu produk pangan yang bertujuan menjaga keawetan dan konsistensi mutu. Produk yang dikemas akan memiliki masa 
simpan relatif lebih lama dibanding dengan tanpa kemasan. Banyak konsumen yang lebih memilih produk yang dikemas dengan kemasan yang lebih menarik. Seperti yang telah kita ketahui, kemasan pada makanan banyak menggunakan polimer yang berasal dari minyak bumi. Kelemahan polimer ini adalah limbahnya sulit diuraikan oleh mikroorganisme dan hanya sedikit dari polimer ini yang bisa didaur ulang sehingga menimbulkan per-masalahan pencemaran terhadap lingkungan.

Plastik merupakan bahan kemasan yang banyak digunakan masyarakat karena ringan, transparan, dapat mengikuti bentuk produk yang dikemas, kuat, ringan, dan harga relatif murah. Namun dewasa ini sampah kemasan plastik tersebut sudah menjadi salah satu sumber pencemaran lingkungan yang cukup serius, terutama karena sampah plastik pada dasarnya sulit hancur oleh perombakan mikroorganisme. Disamping itu, penghancuran sampah plastik dengan pembakaran dinilai kurang tepat karena dapat menimbulkan pencemaran udara dan menghasilkan residu yang cukup berbahaya bagi kesehatan makhluk hidup. Plastik yang berasal dari resin sintetik dalam jangka waktu kurang lebih 400 sampai 500 tahun baru akan terdegradasi di tanah. Sebagai contoh pada tahun 2007 sampah plastik di Indonesia mencapai 6 juta ton (Harian Pelita 2010). Selain itu plastik dalam proses pembuatannya menggunakan minyak bumi dan merupakan produk turunan dari polyester, yang ketersediaannya semakin berkurang dan sulit untuk diperbarui.

Salah satu cara untuk menanggulangi limbah plastik adalah dengan menggunakan kemasan plastik ramah lingkungan yang mampu urai hayati (biodegradable packaging) yang berasal dari polimer alam, hal ini sesuai dengan Directive 94/62 (Packaging \& Packaging Waste).

Penelitian kemasan plastik ramah lingkungan yang mampu urai hayati (biodegradable packaging) yang berasal dari polimer alam telah banyak dilakukan, baik di dalam dan di luar negeri, bahkan sudah banyak yang dipatenkan dan diperdagangkan. Namun demikian, masih diperlukan penelitian lebih lanjut, karena lembaran film yang diperoleh masih memerlukan peningkatan sifat, baik sifat mekanik maupun barrier dan juga pada kestabilan film pada penyimpanan. Seperti diketahui tapioka bersifat hidrofilik, sehingga perlu campuran bahan yang bersifat hidrofobik (Guntarti Supeni 2007). Salah satu alternatif bahan yang mempunyai sifat tersebut adalah menggunakan kitosan sebagai filler dan dengan penambahan aditif lain diharapkan dapat memperbaiki sifat film yang telah diperoleh pada penelitian sebelumnya.

Meskipun penggunaan edible film kelihatan masih baru, penelitian untuk mengembangkan edible film telah dimulai sejak 35 tahun yang lalu (Gennadios dan Weller 1990). Tetapi hanya sedikit dari film-film tersebut yang diaplikasikan secara komersial. Kenyataan ini berkaitan dengan adanya keterbatasan sifat edible film dibandingkan dengan sifat film polimer lainnya. Industri polimer sudah mampu menyediakan material pembungkus makanan yang mempunyai sifat fisik dan penghalang yang lebih baik dibandingkan edible film. Berdasarkan keuntungan yang dimiliki edible film dibandingkan dengan film polimer sintetik, edible film akan lebih banyak digunakan sebagai kemasan makanan pada masa-masa yang akan datang.

Beberapa keuntungan dari penggunaan edible film adalah dapat dimakan, biaya umumnya rendah, kegunaannya dapat mengurangi limbah, mampu meningkatkan sifat organoleptik dan mekanik pada makanan dan mampu menambah nilai nutrisi, dapat berfungsi sebagai carrier/zat pembawa untuk senyawa antimikroba dan antioksidan, dan dapat digunakan sebagai kemasan primer makanan

Kitosan berbentuk spesifik dan mengandung gugus amino dalam rantai karbonnya. Hal ini menyebabkan kitosan bermuatan positif yang berlawanan dengan polisakarida lainnya (Ornum 1992). Kitosan mengandung cukup banyak polisakarida setelah selulosa (Hoagland dan Parris 1996). Berat molekul kitosan 1,036 × 105 dalton (Knorr 1982). Berat molekul ini tergantung dari derajat deasetilasi yang dihasilkan pada saat ekstraksi. Semakin banyak gugus asetil yang hilang dari polimer kitin maka semakin kuat interaksi antarion dan ikatan hidrogen dari kitosan (Ornum 1992).

Kitosan tidak bersifat racun dan merupakan polimer yang bisa diuraikan oleh alam serta mempunyai kesamaan dengan selulosa. Perbedaan antara kitosan dan kitin adalah gugus amina $\left(-\mathrm{NH}_{2}\right)$ pada posisi $\mathrm{C}-2$ dari kitosan sedangkan pada selulosa terdapat gugus hidroksil $(-\mathrm{OH})$. Kitosan memiliki muatan ion positif yang secara kimia memberikan kemampuan berikatan dengan muatan negatif, yaitu lemak, lipid, kolesterol ion logam, protein, dan makromolekul (Li et al. 1992). Kelebihan ini membuat kitin dan kitosan mempunyai nilai komersial yang menarik karena sifat alami kitosan yang sangat bagus dalam hal biokompatibilitas, biodegradable, penyerapan dan kemampuan untuk dibentuk menjadi film, dan penyerapan ion logam (Rout 2001). Tujuan 
dari penelitian ini adalah untuk mengetahui pengaruh kitosan terhadap sifat barrier edible film tapioka termodifikasi.

\section{BAHAN DAN METODE}

\section{Bahan}

Bahan yang digunakan dalam penelitian ini adalah kitosan, dengan spesifikasi sebagai berikut: kadar air 7,65\%, kadar abu $<1 \%$, derajat deasetilasi $>66,42 \%$, viscositas $>200$ Cps, tapioka, etanol, asam asetat glacial 1\%, aquades, natrium asetat, gliserol teknis. Alat yang digunakan terdiri dari neraca, hot plate dengan stirrer, alat uji ketebalan, alat uji WVTR, alat uji $\mathrm{O}_{2} T R$, pompa vakum, media cetak (akrilik), hygrometer, termometer, alat-alat gelas laboratorium.

\section{Metode}

Penelitian dilaksanakan dalam dua tahap yaitu tahap pembuatan edible film dan tahap pengujian sifat barrier edible film.

\section{Tahap Pembuatan Edible Film}

Pembuatan edible film merupakan tahap penelitian utama, dimana pada tahap ini dilakukan dengan tiga tahap yaitu pembuatan larutan edible kitosan, pembuatan larutan edible tapioka termodifikasi, dan pembuatan edible film tapioka.

\section{Pembuatan Larutan Edible Kitosan (modifikasi metode Vojdani dan Torres (1989) dalam Butler dkk. (1996)) \\ Tiga gram kitosan dilarutkan dengan $100 \mathrm{~mL}$ asam asetat glacial 1\%, pada temperatur $50^{\circ} \mathrm{C}$ selama 60 menit dengan pengadukan. Larutan kitosan kemudian divakum dan disaring dengan bantuan pompa vakum, agar gelembung udara dan kotoran yang terperangkap didalam larutan kitosan dapat hilang. Kemudian larutan kitosan dipanaskan kembali pada temperatur $50^{\circ} \mathrm{C}$ selama 15 menit, selama pemanasan dilakukan pengadukan dan penambahan plasticizer (gliserol). Setelah batas waktu 15 menit tercapai, diharapkan campuran telah homogen.}

\section{Pembuatan Larutan Edible Tapioka Termodifikasi}

Pada tahapan ini diawali dengan pembuatan pelarut, yaitu larutan asetat $\left(\mathrm{CH}_{3} \mathrm{COOH}+\mathrm{CH}_{3} \mathrm{COONa}\right) \mathrm{pH} 7$ yang akan digunakan sebagai pelarut tepung pada proses hidrolisis. Setelah itu hidrolisis dilakukan dengan memanaskan campuran 50 gram tepung tapioka dalam $50 \mathrm{~mL}$ pelarut sampai campuran mengental. Pemanasan dilakukan dalam suhu $40^{\circ} \mathrm{C}$. Kemudian dilakukan tahapan pembuatan formulasi untuk lembaran film dengan menggunakan gliserol $15 \%$.

\section{Pembuatan Edible Film}

Pada tahap ini dilakukan penelitian dengan memvariasikan konsentrasi filler pada konsentrasi tertentu, sampai didapatkan konsentrasi yang sesuai sehingga didapatkan nilai dari hasil pengujian sifat fisik/mekanik dari edible film. Filler yang digunakan pada penelitian ini adalah kitosan. Pada tahap ini dilakukan pencampuran antara larutan edible tapioka termodifikasi dengan larutan edible kitosan, dengan memvariasikan penambahan jumlah larutan edible kitosan yang ditambahkan.

Tahap I (trial and error), dilakukan untuk mengetahui jumlah penambahan filler yang optimum,dimana larutan edible tapioka termodifikasi (100\%) ditambah filler (larutan edible kitosan) sebesar 0\%, 50\%, 100\%, 150\%, dan $200 \%$.

Tahap II, dilakukan untuk mengetahui sejauh mana pengaruh penambahan filler terhadap sifat barrier optimal dari edible film yang dihasilkan. Dimana larutan edible tapioka termodifikasi (100\%) ditambah filler (larutan edible kitosan) sebesar 25\%, 50\%, 75\%, 100\%, dan $125 \%$. Pencampuran dilakukan dengan pengadukan selama 30 menit, pada temperatur $40^{\circ} \mathrm{C}$.

Larutan edible film yang terbentuk kemudian dituangkan ke media cetak (akrilik) dengan ukuran $20 \mathrm{~cm} \times 20 \mathrm{~cm}$, kemudian edible film yang telah siap didinginkan pada temperatur $22^{\circ} \mathrm{C}$ selama kurang lebih 24 jam. Pendinginan ini dimaksudkan agar larutan edible film tersebut membeku dan membentuk lembaran edible film. Lembaran edible film kemudian dikelupas dari media cetak, untuk kemudian dilakukan pengujian terhadap karakteristik/sifat barrier dari edible film tersebut.

\section{Laju Transmisi Uap Air Metode Gravimetri (ASTM E 96/E96M-10)}

Laju transmisi uap air terhadap edible film diukur dengan menggunakan metode gravimetri. Bahan penyerap uap air (desikan) diletakkan dalam mangkuk alumunium, kemudian sampel diletakkan di atas mangkuk tersebut sedemikian rupa sehingga menutupi mangkuk tersebut. Tuangkan lilin cair untuk menutupi bagian antara wadah dengan sampel sehingga tidak ada udara masuk.

Cawan ditimbang dengan ketelitian 0,0001 gram kemudian diletakkan dalam humidity chamber Yamato $\mathrm{IH}-42 \mathrm{H}$, ditutup lalu kipas angin dijalankan. Cawan ditimbang tiap hari pada jam yang sama dan ditentukan 
penambahan berat dari cawan. Selanjutnya dibuat grafik hubungan antara pertambahan berat dan waktu, nilai WVTR dihitung dengan persamaan (1).

WVTR $=$ slope $/$ luas sampel $\times 100 \times 100 \mathrm{~m}^{2}$

$$
=\mathrm{g} / \mathrm{m}^{2} / 24 \mathrm{jam}\left(92 \% \mathrm{RH}, 38^{\circ} \mathrm{C}\right) \ldots \ldots . .(1)
$$

\section{Laju Transmisi Oksigen}

Laju transmisi oksigen terhadap edible film diukur dengan menggunakan Metode Manometer (ASTM D 1438-82 Reapproved 1998).

\section{Pengolahan Data}

Data yang diperoleh dari pengukuran dan penimbangan, kemudian diolah dengan menggunakan perhitungan rumus yang terdapat pada masing-masing prosedur pengujian. Hasil yang didapat dari perhitungan kemudian dibandingkan dengan literatur yang ada untuk kemudian dibuat kesimpulan data, yang juga merupakan data akhir dari percobaan.

\section{HASIL DAN PEMBAHASAN}

\section{Hasil Analisis Pengujian}

Dari data yang dihasilkan pada Tabel 1. dapat dilihat bahwa, nilai WVTR terendah adalah $235,14\left(\mathrm{~g} / \mathrm{m}^{2} / 24 \mathrm{jam}\right)$ pada sample 2 dengan perbandingan tapioka $(\mathrm{T})$ dengan kitosan (K) sebesar 100\% (T) : 100\% (K). Laju Oksigen $\left(\mathrm{O}_{2} \mathrm{TR}\right)$ terendah $0,063\left(\mathrm{cc} / \mathrm{m}^{2} / 24 \mathrm{jam}\right)$ pada sampel 4 dengan perbandingan Tapioka $(\mathrm{T})$ dengan Kitosan (K) sebesar 100\% (T) : 200\% (K). Jika diperhatikan pada kolom $\mathrm{O}_{2} T R$ dapat terlihat bahwa sejalan dengan penambahan komposisi kitosan, maka nilai $\mathrm{O}_{2} T R$ cenderung turun.

Tabel 1. Hasil analisa trial and error pada nilai WVTR dan $\mathrm{O}_{2} T R$

\begin{tabular}{lcccc}
\hline No & $\begin{array}{c}\text { Komposisi } \\
(\mathrm{T}: \mathrm{K}) \\
(\%)\end{array}$ & $\begin{array}{c}\text { WVTR } \\
\left(\mathrm{g} / \mathrm{m}^{2} / 24 \mathrm{jam}\right)\end{array}$ & $\begin{array}{c}\mathrm{O}_{2} T R \\
\left(\mathrm{cc} / \mathrm{m}^{2} / 24 \mathrm{jam}\right)\end{array}$ & Ket \\
\hline 1. & $\begin{array}{c}\text { Blanko } \\
(100: 0)\end{array}$ & 244,26 & 63,467 & \\
2. & $\begin{array}{c}\text { Sampel } 1 \\
(100: 50)\end{array}$ & 248,01 & 0,568 & \\
3. & $\begin{array}{c}\text { Sampel } 2 \\
(100: 100)\end{array}$ & $\mathbf{2 3 5 , 1 4}$ & $\mathbf{0 , 6 2 9}$ & Optimum \\
4. & $\begin{array}{c}\text { Sampel 3 } \\
(100: 150)\end{array}$ & 480,12 & 0,095 & \\
5. & $\begin{array}{l}\text { Sampel 4 } \\
(100: 200)\end{array}$ & 356,88 & 0,063 & \\
\hline
\end{tabular}

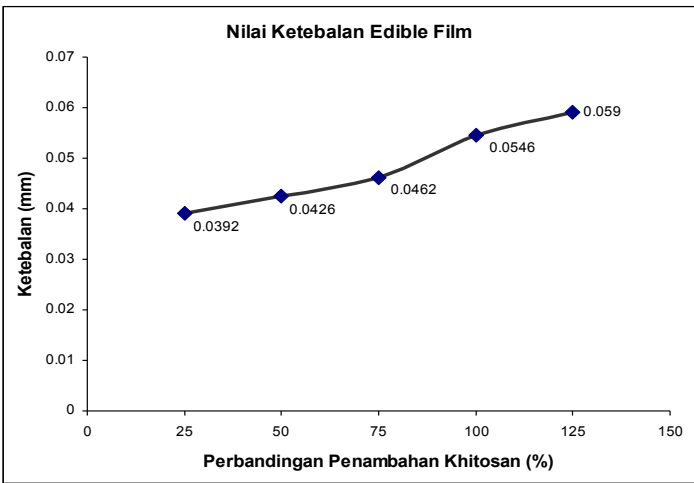

Gambar 1. Hasil uji ketebalan edible film

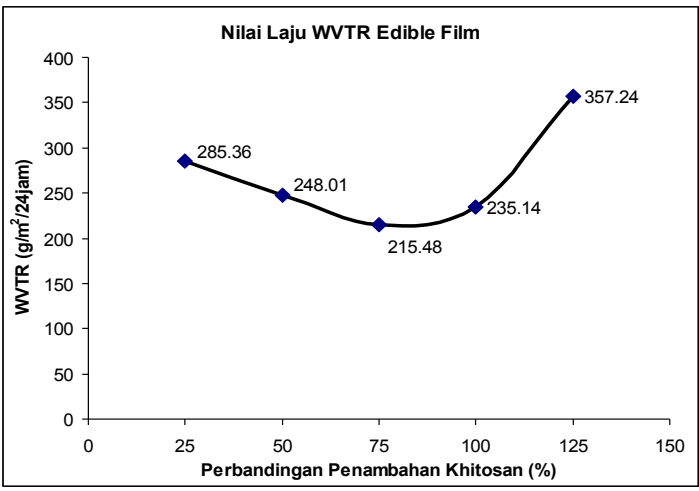

Gambar 2. Hasil uji WVTR edible film

Pada penelitian ini sampel 2 dinyatakan optimum karena memiliki nilai WVTR yang terendah dan nilai $\mathrm{O}_{2} T R$ kurang dari $1 \mathrm{cc} / \mathrm{m}^{2} / 24 j a m$. Pada tahap penelitian selanjutnya komposisi penambahan kitosan divariasikan menjadi 25\%, 50\%, 75\%, 100\% dan $125 \%$, dengan komposisi tapioka tetap (100\%). Dari formulasi tersebut di atas, edible film yang dihasilkan diuji ketebalan dan sifat barriemya dengan hasil seperti terlihat pada Gambar 1 dan Gambar 2.

\section{Hasil Analisis Ketebalan}

Ketebalan edible film dipengaruhi oleh banyaknya total padatan dalam larutan dan ketebalan cetakan. Dengan cetakan yang sama, edible film yang terbentuk akan lebih tebal apabila volume larutan yang dituangkan ke dalam cetakan lebih banyak. Hasil analisa ketebalan didapatkan bahwa edible film yang ditambahkan kitosan memiliki nilai ketebalan terendah 0,0392 $\mathrm{mm}$ dan tertinggi sebesar 0,059 $\mathrm{mm}$. Hasil pengukuran tersebut memperlihatkan adanya kecenderungan pening-katan rata-rata ketebalan edible film dengan adanya penambahan kitosan. 
Hasil Analisis Laju Transmisi Uap Air (WVTR)

Perpindahan uap air akan terjadi apabila di dalam makanan terdapat perbedaan aktivitas air $\left(a_{w}\right)$. Perbedaan kelembaban produk makanan dengan lingkungan sekitarnya ini dapat dikontrol dengan mengatur $a_{w}$ pada makanan, ataupun dengan membungkusnya dengan suatu lapisan edible film yang mempunyai sifat penghalang (barrier) yang baik terhadap transmisi uap air dan secara efektif akan mampu mencegah kehilangan uap air. Transmisi uap air sangat dipengaruhi oleh $\mathrm{RH}$, temperatur, ketebalan, jenis dan konsentrasi plasticizer serta sifat bahan pembentuk edible film.

Umumnya edible film yang terbuat dari bahan protein dan polisakarida mempunyai nilai transmisi uap air yang tinggi. Hal ini disebabkan karena bahan tersebut merupakan polimer polar dan mempunyai jumlah ikatan hidogen yang besar, sehingga menghasilkan penyerapan air pada $\mathrm{RH}$ tinggi. Akibatnya, penyerapan air tersebut akan mengganggu interaksi rantai intermolekuler, yang kemudian diikuti dengan peningkatan difusifitas dan mampu menyerap uap air dari udara (Krochta et al. 1994).

Dalam penelitian ini digunakan kitosan sebagai bahan filler. Berdasarkan hasil photo SEM Gambar 3 memperlihatkan struktur polimer pembentuk kitosan berupa polimer serat panjang dan mempunyai pori yang besar. Penyerapan uap air yang terjadi disebabkan karena adanya proses difusi aktif yang melibatkan pelarutan uap air pada edible film, kemudian berdifusi melalui edible film dan dilepaskan pada sisi yang lain. Selain itu, ketika film hidrofilik menyerap air dan menggumpal, molekul air yang ditambahkan kemudian akan bersifat mobile, menyebabkan mobilitas rata-rata dari molekul air meningkat dan akibatnya terjadi peningkatan barrier (laju transmisi uap air) (Krochta et al. 1994).

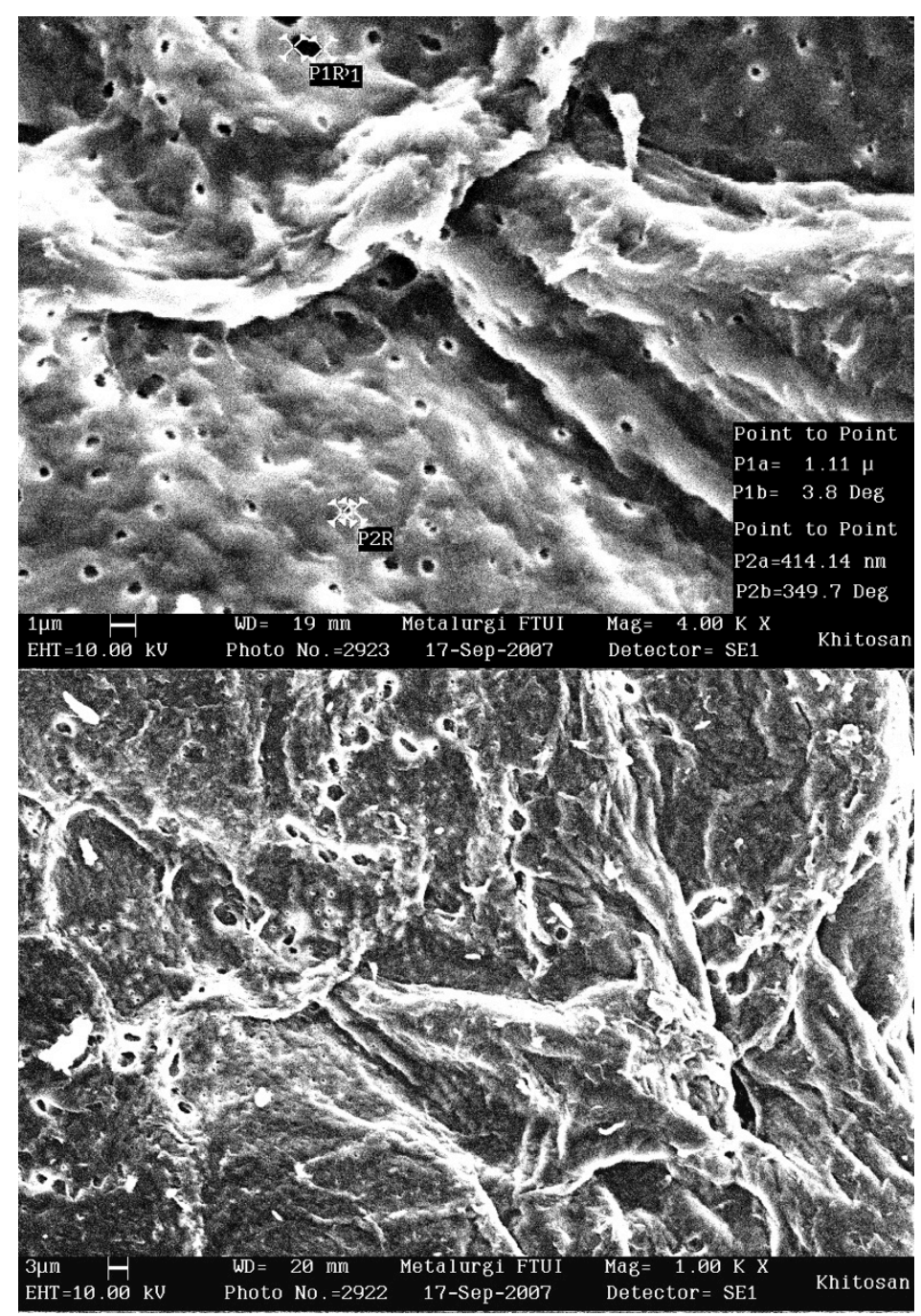

Gambar 3. Foto SEM kitosan 
Sifat barrier pada edible film yang ditambahkan larutan kitosan sebagai filler memiliki nilai terendah 215,48 $\mathrm{g} / \mathrm{m}^{2} / 24$ jam dan nilai tertinggi $357,24 \mathrm{~g} / \mathrm{m}^{2} / 24$ jam. Besarnya nilai barrier uap air pada edible film dengan penambahan filler kitosan, disebabkan karena edible film yang dihasilkan masih dipengaruhi oleh sifat bahan baku (tapioka) dan filler (kitosan) yang hidrofilik.

Gambar 4 memperlihatkan edible film tapioka dengan penam-bahan gliserol pada konsentrasi $15 \%$.

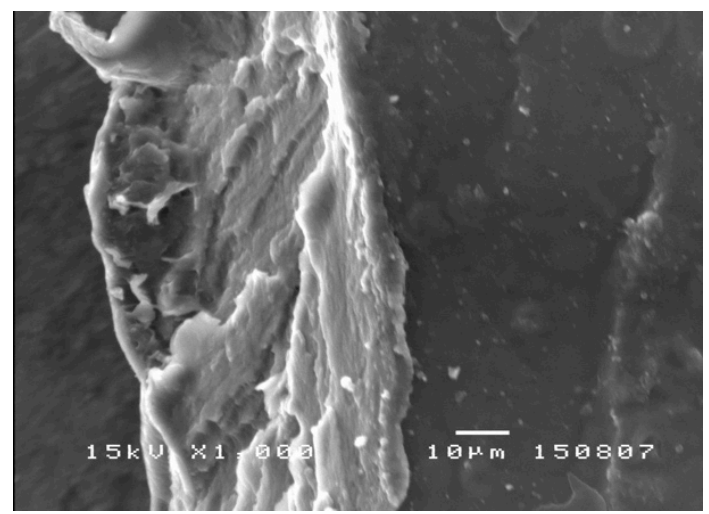

Gambar 4. Foto SEM edible film tapioka tanpa penambahan filler kitosan

Pada penambahan gliserol konsentrasi $15 \%$, molekul-molekul gliserol masuk kedalam celah-celah rantai molekul polimer kitosan secara merata. Irisan yang dilakukan pada edible film tapioka dengan penambahan gliserol $15 \%$ memperlihat-kan bahwa selain gliserol berfungsi sebagai pengisi celah antar rantai molekul polimer, juga berfungsi membentuk lapisan pada permukaan edible film yang dihasilkan.

Penambahan komposisi filler kitosan ke dalam larutan edible film tapioka, mempengaruhi laju barrier uap air. Pada penambahan 25\% sampai $50 \%$ filler kitosan ke dalam 100\% larutan edible film tapioka, menghasilkan nilai WVTR yang relatif menurun. Hal ini disebabkan filler kitosan yang ditambahkan ke dalam larutan edible film tapioka, belum merata mengisi poripori atau celah ikatan antar polimer yang terbentuk (Gambar 5a).

Pada penambahan filler kitosan sebesar $75 \%$ mempunyai nilai WVTR yang optimal, hal ini disebabkan filler kitosan yang ditambahkan sudah merata mengisi pori-pori atau celah ikatan antar polimer yang terbentuk (Gambar 5b). Penambahan filler kitosan pada konsentrasi lebih dari $75 \%$, akan mengakibatkan nilai laju WVTR akan bertambah besar. Hal ini disebabkan karena filler yang ditambahkan akan membentuk lapisan di atas edible film tapioka yang terbentuk (Gambar 5c).

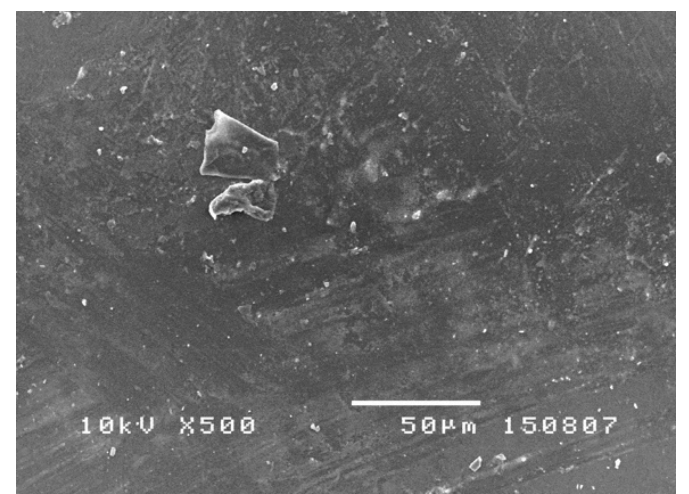

(a) Edible film tapioka dengan penambahan filler kitosan $50 \%$

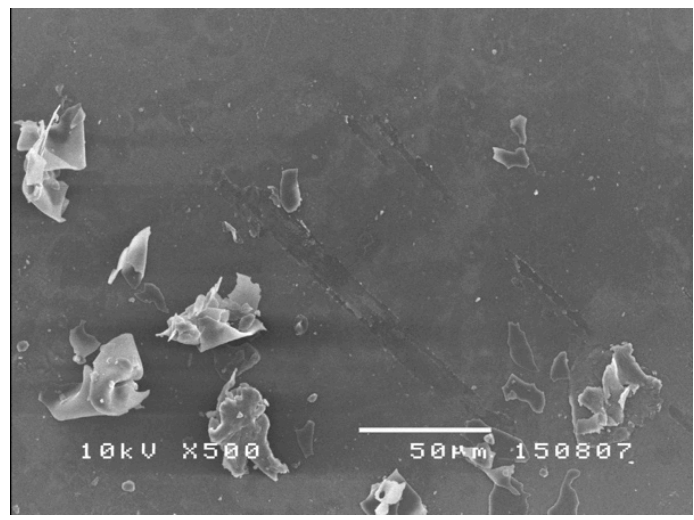

(b) Edible film tapioka dengan penambahan filler kitosan $75 \%$

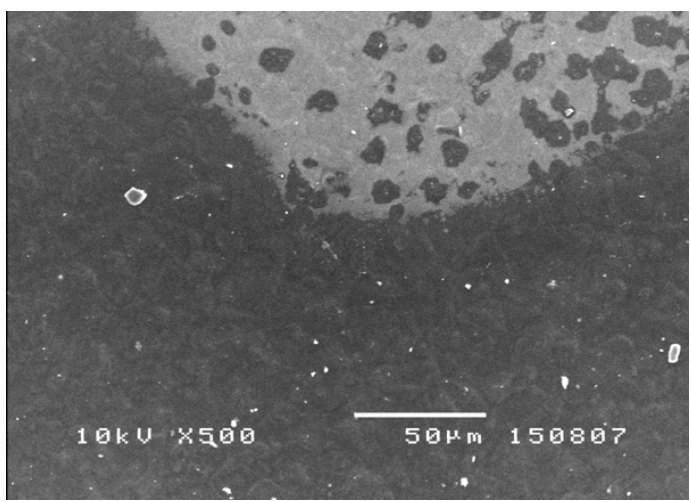

(c) Edible film tapioka dengan penambahan filler kitosan $100 \%$

Gambar 5. Foto SEM edible film (pembesaran $500 \mathrm{x}$ )

Dari data di atas dapat dilihat bahwa peningkatan konsentrasi larutan edible kitosan (kitosan dan gliserol) mengakibatkan peningkatan nilai barrier uap air dari edible film tapioka. Hal ini disebabkan karena gliserol (plasticizer) dan kitosan dalam pembuatan larutan edible kitosan mempunyai sifat yang hidrofilik, 
sehingga kitosan dan gliserol justru akan menghasilkan penyerapan uap air.

\section{Hasil Analisis Laju Transmisi Gas Oksigen $\left(\mathrm{O}_{2} T R\right)$}

Pengaturan konsentrasi oksigen dalam produk makanan dimaksudkan untuk mempertahankan/memperpanjang masa simpan makanan. Oksigen berhubungan dengan berbagai reaksi degradasi yang terjadi dalam penyimpanan, $\mathrm{RH}$, penambahan plasticizer, dan tipe produk yang akan dikemas. Edible film yang terbuat dari protein dan polisakarida mempunyai jumlah besar, gugus hidroksil tersebut makanan seperti ketengikan minyak, pertumbuhan sifat barrier yang sangat baik terhadap oksigen (Gontard et al. 1993). Hal ini disebabkan karena polisakarida mempunyai gugus hidroksil dalam mikroba, reaksi browning enzimatis, respirasi, dan lain-lain. Oleh karena itu sifat barrier film terhadap oksigen sangat diperlukan. Sifat barrier terhadap gas dipengaruhi oleh beberapa faktor seperti sifat alami gas, struktur material, temperatur, waktu menciptakan interaksi rantai polimer yang kuat sehingga membatasi pergerakan rantai dan menyebabkan sifat barrier terhadap oksigen menjadi rendah (Krochta et al. 1994).

Dari hasil percobaan diperoleh nilai barrier oksigen edible film yang mendapat tambahan filler kitosan, memiliki nilai barrier terhadap oksigen yang cenderung turun. Nilai barrier terhadap oksigen terendah $0,074 \mathrm{cc} / \mathrm{m}^{2} / 24 \mathrm{jam}$ dan nilai tertinggi $0,94 \mathrm{cc} / \mathrm{m}^{2} / 24 \mathrm{jam}$. Pada konsentrasi penambahan filler kitosan sebesar $100 \%$, nilai $\mathrm{O}_{2} T R$ mengalami peningkatan, hal ini disebabkan karena timbulnya porositas pada edible film tapioka yang terbentuk (Gambar 6).
Dari keseluruhan hasil penelitian, maka edible film yang terbentuk masuk dalam Grade 5 dari standar JIS Z 1707-1997. Edible film tersebut sangat baik diaplikasikan sebagai bahan pengemas buah-buahan, sayur-sayuran, dodol dan makanan berminyak.

\section{Perbandingan Hasil Penelitian}

Sampai saat ini sudah banyak penelitian yang dilakukan untuk mengembangkan edible film sebagai salah satu bentuk kemasan yang efektif. Perbandingan dilakukan untuk mengetahui keunggulan dan kelemahan suatu edible film yang terbuat dari bahan yang berbeda. Karakteristik edible film yang akan dibandingkan hanya karakteristik ketebalan, barrier terhadap uap air, dan barrier terhadap gas oksigen.

Dari penelitian yang telah dilakukan diketahui bahwa edible film hasil penelitian yang dilakukan, mempunyai ketebalan yang relatif lebih kecil dibandingkan dengan ketebalan dari hasil penelitian yang telah dilakukan sebelumnya.

Kualitas edible film sangat ditentukan oleh besar kecilnya nilai laju transmisi uap air (WVTR) dan laju transmisi gas oksigen $\left(\mathrm{O}_{2} T R\right)$, semakin kecil nilai $W V T R$ dan $\mathrm{O}_{2} T R$ yang dihasilkan oleh suatu edible film maka kualitas edible film tersebut akan semakin baik karena tidak hanya dapat diaplikasikan pada sayur dan buah-buahan. Tetapi penggunaan edible film tidak hanya ditentukan oleh besar kecilnya nilai laju WVTR dan $\mathrm{O}_{2} T R$, melainkan dari bagaimana karakteristik daripada produk yang akan dikemas.

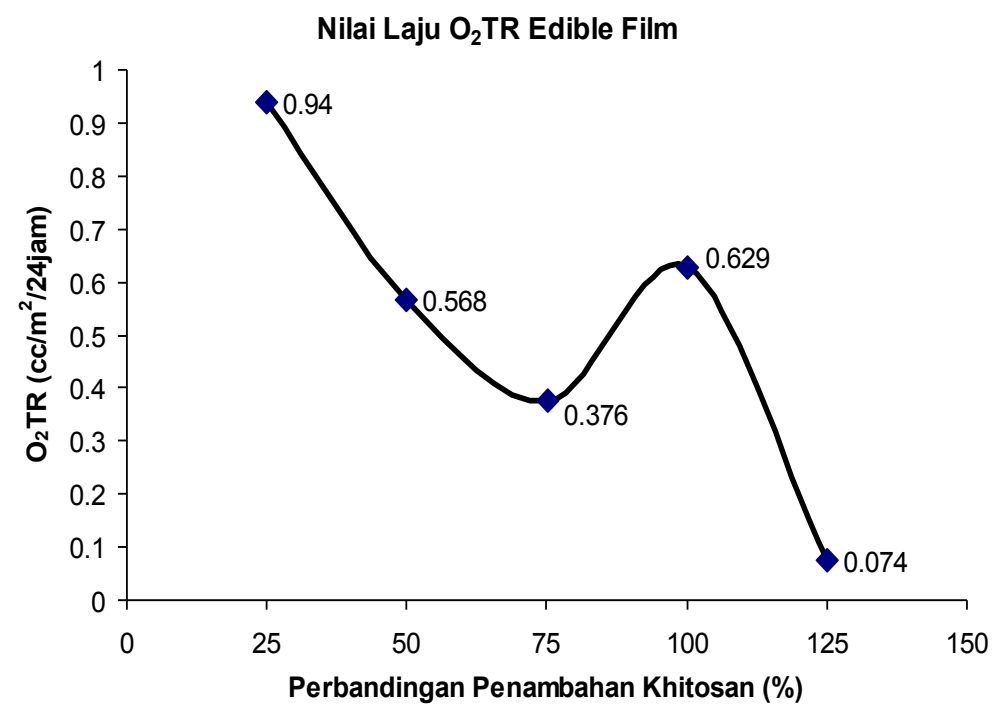

Gambar 6. Hasil uji $\mathrm{O}_{2} T R$ edible film 
Nilai laju transmisi uap air (WVTR) yang diperoleh dari penelitian yang dilakukan mempunyai nilai yang relatif sama, dibandingkan dengan nilai laju transmisi uap air (WVTR) yang diperoleh dari hasil penelitian yang dilakukan sebelumnya. Nilai laju transmisi gas oksigen $\left(\mathrm{O}_{2} T R\right)$ yang diperoleh dari penelitian yang dilakukan mempunyai nilai yang relatif lebih kecil, dibandingkan dengan nilai laju transmisi uap air (WVTR) yang diperoleh dari hasil penelitian yang dilakukan sebelumnya.

\section{KESIMPULAN}

Penambahan kitosan pada edible film tapioka dapat memperkecil laju barrier terhadap oksigen. Penggunaan paling optimal adalah tapioka: kitosan $(1: 0,75)$, didapat nilai laju WVTR minimum sebesar $215,48 \mathrm{~g} / \mathrm{m}^{2} / 24$ jam dan nilai laju $\mathrm{O}_{2} T R$ sebesar 0,376 (cc/m $\left./ 24 \mathrm{jam}\right)$. Dari hasil analisis SEM terlihat pada penambahan filler kitosan sebesar $75 \%$ mempunyai nilai WVTR yang optimal, hal ini disebabkan filler kitosan yang ditambahkan sudah merata mengisi pori-pori atau celah ikatan antar polimer yang terbentuk. Penambahan kitosan tidak dapat meningkat-kan grade pada JIS Z 17071997, Plastic Film for Food Packaging.

\section{DAFTAR PUSTAKA}

ASTM. Standard Test Methods for Water Vapour Transmission Rate of Materials. E 96.

ASTM. Reapproved 1998. Standard Test Methods for Oxygen Gas Transmission Rate of Materials. D1438-82.

Buttler, B. L., P. J. Vergant, R. F. Testin, J. M. Bunn, and J. L. Wiles. 1996. Mechanical properties barrier properties of edible chitosan films as effected by composition and storage. J. Of Food Sci. 61 (5): 953-961.

Directive 94/62/EC. Packaging and Packaging Waste.

Gontard, N. and S. Guilbert. 1993. Water and glycerol as plasticizers effect mechanical and water vapor barrier properties of edible wheat gluten film. Journal Food Science. 57: 190-195.

Gannadios, A. and L.W. Curtis. 1990. Edible film and coating for wheat and corn proteins. Journal of Food Technology.

Guntarti Supeni dkk. 2007. Laporan Penelitian Formulasi dan Aplikasi Kemasan Layak Santap (Edible film) dari Tapioka Termodifikasi. Balai Besar Kimia dan Kemasan, Kementerian Perindustrian RI.
Hoagland, P.D. and N. Parris. 1996. Chitosan / Pectin laminated film. Journal Agricultural. Food Chemical. 44: 19151919.

Harian Pelita, Kamis 16 September 2010.

Knorr, D. 1982. Functional properties of chitin and chitosan. J. Food Sci. 47: 593-595.

Krochta, J.M., E.A. Baldwin and M.O. NisperosCarriedo.1994. Edible Coatings and Films to Improve Food Quality. Technomic Publication. Co. Inc., USA.

Li, Q., Dunn, E.T., Grandmaison, E.W. and Goosen M.F.A. 1992. Applications and properties of chitosan. J. Bioactive and Compatible Polym. 7: 370-397.

Ornum, J.U. 1992. Shrimp Waste Must It Be Wasted. Infofish. 6: 48.

Rout, S. K. 2001. Physicochemical, Functional, and Spectroscopic analysis of crawfish chitin and chitosan as affected by process modification. Dissertation.

Suryo Irawan. 2008. Thesis Karakterisasi Edible film dari Kitosan. Program PascaSarjana FMIPA-Kimia, Universitas Indonesia. 